\title{
Insulin regulates the expression of adiponectin and adiponectin receptors in porcine adipocytes
}

\author{
Bing Hsien Liu ${ }^{\mathrm{a}}$, Ya Chin Wang ${ }^{\mathrm{a}}$, Shinn Chih Wu ${ }^{\mathrm{a}, \mathrm{b}}$, Harry John Mersmann ${ }^{\mathrm{a}}$, \\ Winston Teng Kuei Cheng a,b, Shih Torng Ding a,b,* \\ a Department of Animal Science and Technology, National Taiwan University, Taipei 106, Taiwan \\ ${ }^{\mathrm{b}}$ Institute of Biotechnology, National Taiwan University, Taipei 106, Taiwan
}

Received 28 March 2007; received in revised form 4 October 2007; accepted 4 October 2007

\begin{abstract}
Adiponectin is an adipocyte-derived hormone that can improve insulin sensitivity. Its functions in regulating glucose utilization and fatty acid metabolism in mammals are mediated by two subtypes of adiponectin receptors (AdipoR1 and AdipoR2). This study was conducted to determine the effect of insulin on the expression of adiponectin and its receptors. We demonstrated that in the presence of $10 \mathrm{nM}$ insulin, addition of $1 \mu \mathrm{M}$ of insulin or rosiglitazone (a peroxisome proliferator-activated receptor $\gamma$ (PPAR $\gamma$ ) agonist) had no effect on the expression of adiponectin and AdipoR genes in differentiated porcine adipocytes. However, the addition of $1 \mu \mathrm{M}$ insulin plus $1 \mu \mathrm{M}$ rosiglitazone significantly increased the AdipoR2 mRNA in differentiated porcine adipocytes. Using the phosphatidylinositol 3-kinase inhibitor (PI3K inhibitor, LY 294002), we found that insulin inhibited the expression of AdipoR2 through the PI3K pathway and this inhibition was blocked by addition of rosiglitazone. When porcine adipocytes were cultured without insulin, supplementation with $10 \mathrm{nM}$ insulin inhibited the expression of AdipoR2 and this inhibition effect was also blocked by addition of rosiglitazone. Therefore, these data suggest that a PPAR $\gamma$ agonist increases expression of AdipoR2 and that insulin inhibits the expression of AdipoR2 through the PI3K pathway.
\end{abstract}

(C) 2007 Elsevier Inc. All rights reserved.

Keywords: Adiponectin; Adiponectin receptors; Insulin; Pigs; PPAR $\gamma$

\section{Introduction}

Adiponectin is an adipocyte-produced protein hormone circulating in the blood [1-4]. Administration of adiponectin to mice decreases plasma glucose, free fatty acids, and triglycerides, and increases muscle fatty acid oxidation and induces weight loss [5]. The function of adiponectin is carried out through the activation of

\footnotetext{
* Corresponding author at: Department of Animal Science and Technology, National Taiwan University, 50, Lane 155, Kee-Long Rd. Sec. 3, Taipei 106, Taiwan. Tel.: +886 953610078; fax: +886 227324070. E-mail address: sding@ntu.edu.tw (S.T. Ding).
}

AMP-activated protein kinase [4]. Adiponectin-deficient mice are mildly insulin-resistant and glucose intolerant when fed a standard diet [6,7]. Furthermore, decreased circulating adiponectin concentrations are associated with insulin resistance, obesity, and type 2 diabetes $[8,9]$. Therefore, adiponectin may modify the function of insulin in mammals.

Thiazolidinediones (a class of type 2 diabetes drugs), ligands for peroxisome proliferator-activated receptor $\gamma$ $(\operatorname{PPAR} \gamma)$ increase adiponectin expression and plasma adiponectin concentration in rodents $[8,10]$. Thiazolidinediones also increase the expression of adiponectin in type 2 diabetes mellitus and obese patients [11,12]. Dual activation of PPAR $\alpha$ and $\gamma$ increases serum 
adiponectin concentration in adipose tissue of obese diabetic KKAy mice [13]. Furthermore, there is a functional PPAR-response element (PPRE) in the promoter region of the adiponectin gene [14]. Thus, adiponectin should be regulated by PPAR $\gamma$ and its ligands.

Yamauchi et al. [15] first cloned the cDNA encoding adiponectin receptors 1 (AdipoR1) and 2 (AdipoR2) from the human and mouse. These two adiponectin receptors contain seven transmembrane domains, but they are structurally and functionally distinct from G-protein-coupled receptors [15]. Both AdipoR1 and AdipoR2 can mediate the function of adiponectin and the expression of these two receptors is regulated by PPAR $\gamma$ ligands or a combination of ligands for PPAR $\alpha$ and PPAR $\gamma$ in obese patients and mice [11-13]. In order to clarify the regulation of gene expression of adiponectin receptors in pigs, we have cloned the full-length cDNA from porcine AdipoR genes [16]; in this study, we determined the insulin regulation of AdipoR1 and AdipoR2 expression in adipocytes. We also investigated the interaction of a PPAR $\gamma$ ligand and insulin on the expression of adiponectin and AdipoR genes in porcine adipocytes.

\section{Materials and methods}

\subsection{Isolation of porcine stromal vascular $(S / V)$ cells}

The animal protocol was approved by the Experimental Animal Care and Use Committee at National Taiwan University. Porcine adipose tissue samples were digested and $\mathrm{S} / \mathrm{V}$ cells were isolated and cultured as previously described [17,18]. In brief, adipose tissue from 9-day-old crossbred pigs was removed from the dorsal s.c. depot in the neck, shoulder, and back regions. The slices of adipose tissue $(10 \mathrm{~g})$ were digested with $4500 \mathrm{IU}$ of collagenase (Sigma C6885; Sigma, St. Louis, MO, USA) in sterile Krebs Ringer bicarbonate buffer at $37^{\circ} \mathrm{C}$ for $90 \mathrm{~min}$. The $\mathrm{S} / \mathrm{V}$ cell fraction was isolated by centrifugation at $800 \times g$ for $10 \mathrm{~min}$ and the pellet was washed three times by resuspension with DMEM/F12 medium (Sigma D8900) supplemented with $\mathrm{NaHCO}_{3}(14 \mathrm{mM}), 100 \mathrm{U}$ penicillin/mL, $100 \mathrm{mg}$ streptomycin $/ \mathrm{mL}, 1.5 \mu \mathrm{g} / \mathrm{mL}$ amphotericin B and $10 \%$ fetal bovine serum. Before the last washing step, the $\mathrm{S} / \mathrm{V}$ cell fraction was treated with red blood cell lysing buffer $\left(155 \mathrm{mM} \mathrm{NH}_{4} \mathrm{Cl}, 5.7 \mathrm{mM}\right.$ $\mathrm{K}_{2} \mathrm{HPO}_{4}, 0.1 \mathrm{mM}$ EDTA at $\mathrm{pH}$ 7.3) to remove red blood cells which may reduce adhesion of $\mathrm{S} / \mathrm{V}$ cells. The washed S/V cells were resuspended in DMEM/F12 containing $10 \%$ fetal bovine serum and plated at a concentration of $5 \times 10^{4}$ cells $/ \mathrm{cm}^{2}$. The $\mathrm{S} / \mathrm{V}$ cells were then cultured at $37^{\circ} \mathrm{C}$ in air containing $5 \% \mathrm{CO}_{2}$ for $48 \mathrm{~h}$ to let the cells fully attach to the dish (Fig. 1).

\subsection{Cell culture and differentiation of porcine adipocytes}

After $48 \mathrm{~h}$ of initial incubation for proliferation (defined as day 0), the medium was removed and replaced by serum-free, hormone-supplemented differentiation medium (DMEM/F12 containing $\mathrm{NaHCO}_{3}$ $(14 \mathrm{mM}), 25 \mathrm{mM}$ glucose, $1 \mu \mathrm{M}$ bovine insulin, $10 \mu \mathrm{g}$ transferrin $/ \mathrm{mL}, 2 \mathrm{mM}$ L-glutamine, $33 \mu \mathrm{M}$ biotin, $17 \mu \mathrm{M}$ pantothenate, $100 \mathrm{nM}$ dexamethasone, $1 \mathrm{nM}$ triiodothyronine, $100 \mathrm{U}$ penicillin/mL, $100 \mathrm{mg}$ strep-

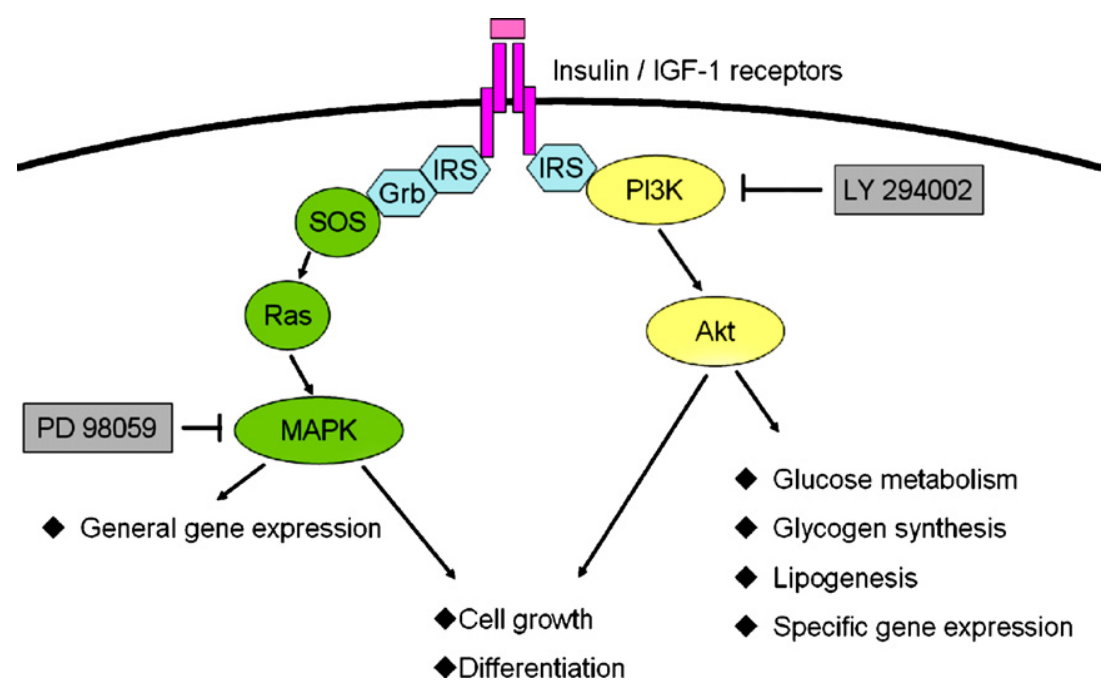

Fig. 1. Signal transduction pathway for insulin. The insulin/IGF-1 receptors function through activating PI3K or MAPK which then regulates glucose, lipid, and protein metabolism (modified from Saltiel and Kahn, 2001 [41]). LY 294002 is the inhibitor for PI3K and PD 98059 is the inhibitor for MAPK. 

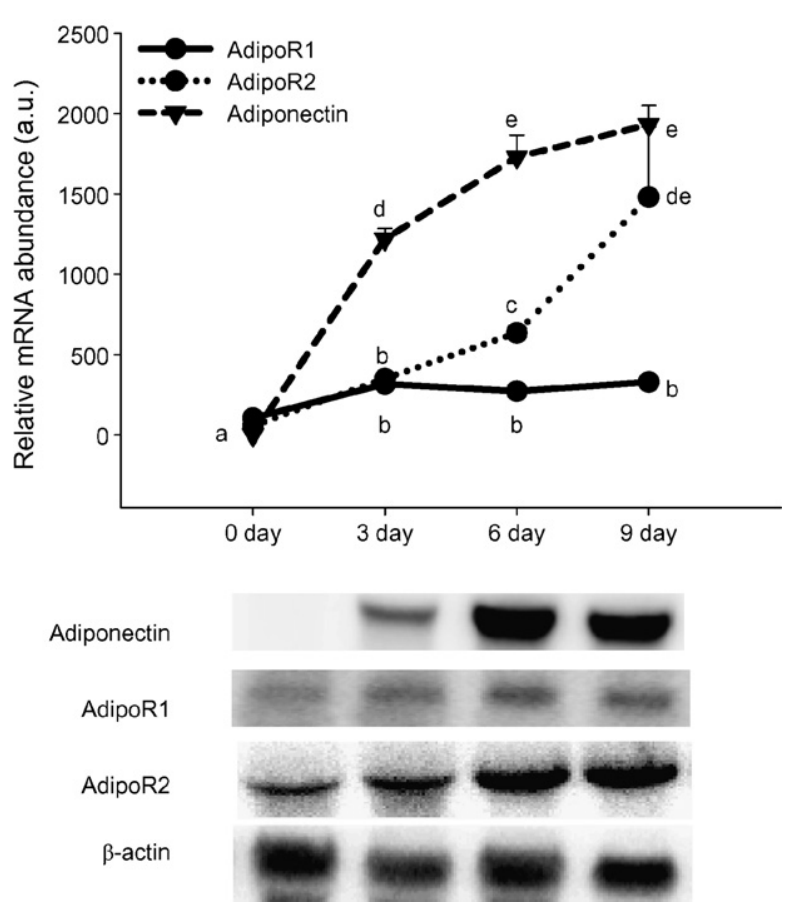

Fig. 2. Differentiation-dependent adiponectin, and AdipoR genes expression in porcine adipocytes. Porcine S/V cells were differentiated and on the indicated days $(0,3,6$, and 9), total RNA was extracted for detecting adiponectin, AdipoR1, AdipoR2, and $\beta$-actin gene expression by Northern analysis. The results are the means of three independent experiments with S/V cells isolated from three different pigs. The average of AdipoR 1 day 0 data was set to 100 and other data were expressed as relative abundance to this value. Each point represents the mean \pm S.E.M. and mRNA values were normalized to $\beta$-actin. Data were analyzed by ANOVA; means without a common letter differ, $P \leq 0.05$, from 100 (a.u. for 0-day AdipoR1).

tomycin $/ \mathrm{mL}, 1.5 \mu \mathrm{g} / \mathrm{mL}$ amphotericin $\mathrm{B}$ and $1 \mu \mathrm{M}$ rosiglitazone) for 3 days to induce adipogenesis. The medium was then changed to differentiation medium without rosiglitazone. The medium was replaced every 3 days. After 9 days, up to $90-95 \%$ of the attached cells were differentiated to cells with visible lipid droplets. For studying the expression of genes during porcine adipocyte differentiation, porcine $\mathrm{S} / \mathrm{V}$ cells were induced to differentiation and on the indicated days $(0,3,6$, and 9), total RNA was extracted for measuring adiponectin, AdipoR1, AdipoR2, and $\beta$-actin mRNA by Northern analysis. The results were the means of three independent experiments, each with $\mathrm{S} / \mathrm{V}$ cells isolated from a different pig (Fig. 2).

\subsection{Time-course effect of insulin and rosiglitazone}

To study the effect of insulin on the expression of adiponectin and AdipoRs, 9-day-differentiated adipocytes were washed with phosphate-buffered saline and then cultured in low glucose DMEM/F12 (DMEM, Sigma D5523: nutrient mixture F12, Sigma N6760 = 1:1, with a final glucose concentration of $7.78 \mathrm{mM}$ ) with $10 \mathrm{nM}$ insulin for $6 \mathrm{~h}$, and then $1 \mu \mathrm{M}$ insulin (a concentration reported to be effective with 3T3-L1 cells [19]), $1 \mu \mathrm{M}$ rosiglitazone [20] or insulin + rosiglitazone were added for 2,12 , or $24 \mathrm{~h}$. Total RNA was extracted to measure adiponectin, AdipoR1, AdipoR2, and $\beta$-actin mRNA abundance by Northern analysis. The results were the means of four independent experiments, each using cells isolated from a different pig (Fig. 3).

\subsection{Inhibition of insulin signal pathways}

There are two major signal transduction pathways, one through mitogen-activated protein kinase (MAPK) and one through phosphatidylinositol 3-kinase (PI3K), mediating the insulin effects on regulation of gene expression (Fig. 1). Nine-day-differentiated adipocytes were cultured in low glucose $(7.78 \mathrm{mM})$ DMEM/F12 with $10 \mathrm{nM}$ insulin for $6 \mathrm{~h}$. After $6 \mathrm{~h}, 1 \mu \mathrm{M}$ insulin $+1 \mu \mathrm{M}$ rosiglitazone were added to treat cells and incubation was continued for $24 \mathrm{~h}$. At $6 \mathrm{~h}$, the mitogenactivated protein kinase (MAPK) inhibitor, PD 98059 at $25 \mu \mathrm{M}$ [21] or the phosphatidylinositol 3-kinase (PI3K) inhibitor, LY 294002 at $10 \mu \mathrm{M}$ were added to some plates along with insulin + rosiglitazone; incubation was continued for $24 \mathrm{~h}$. Total RNA was extracted for determining AdipoR1, AdipoR2, and $\beta$-actin gene expression by Northern analysis. The results were the means of four independent experiments, each using cells isolated from a different pig (Fig. 4).

\subsection{Insulin, rosiglitazone, and PI3K inhibitor treatments}

Nine-day-differentiated adipocytes were cultured in low glucose $(7.78 \mathrm{mM})$ DMEM/F12 without insulin. After $6 \mathrm{~h}, 10 \mathrm{nM}$ insulin, $1 \mu \mathrm{M}$ insulin, $1 \mu \mathrm{M}$ rosiglitazone, or $10 \mu \mathrm{M}$ LY 294002 were added singly or in combination to study the effect of insulin and an insulin sensitizer on the expression of AdipoRs. Total RNA was extracted for determining adiponectin, AdipoR2, and $\beta$ actin gene expression by Northern analysis. The results were the means of four independent experiments, each using cells isolated from a different pig (Fig. 5).

\subsection{Northern analysis}

Total RNA was extracted by the guanidiniumphenol-chloroform extraction method [22]. The 

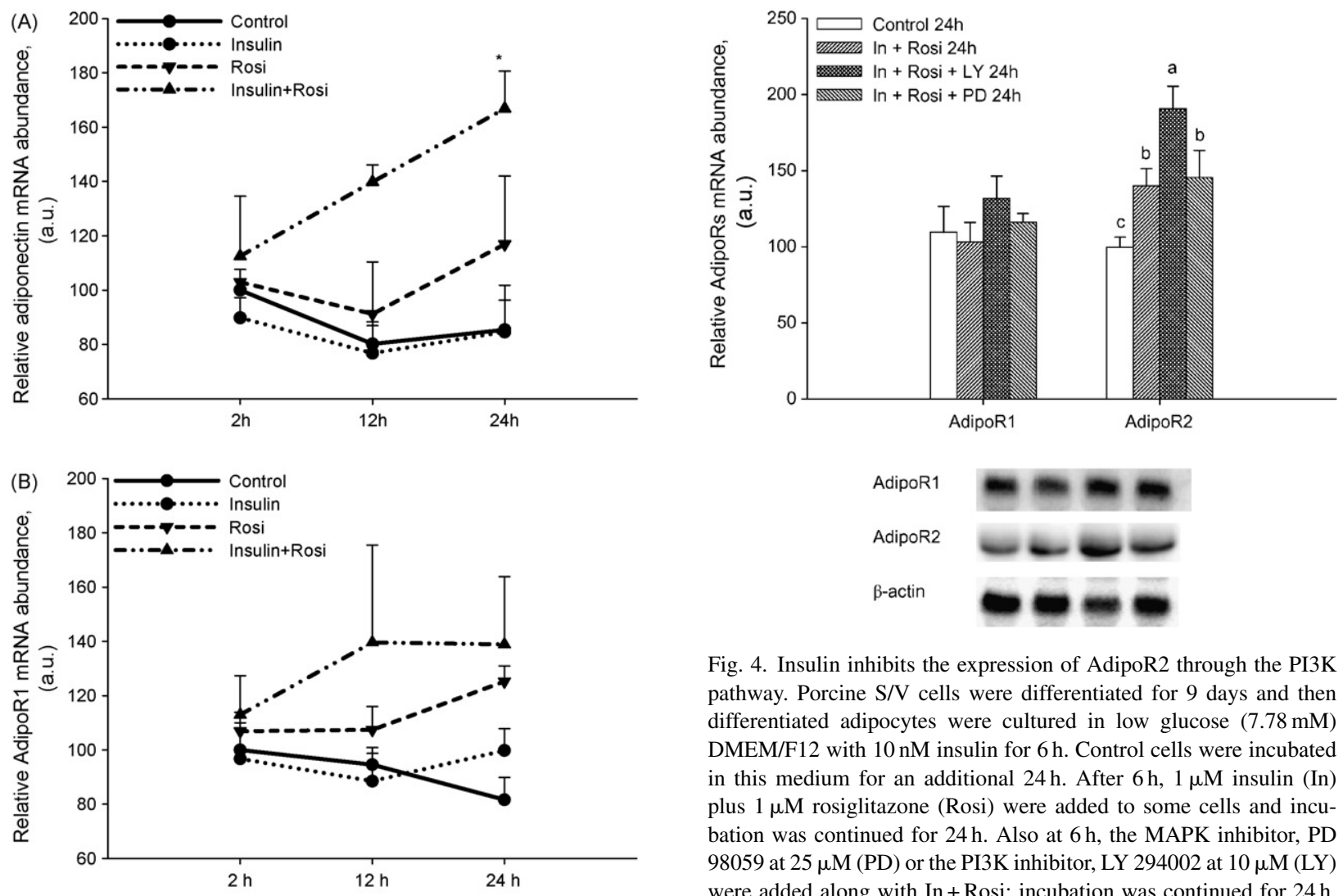

Fig. 4. Insulin inhibits the expression of AdipoR2 through the PI3K pathway. Porcine S/V cells were differentiated for 9 days and then differentiated adipocytes were cultured in low glucose $(7.78 \mathrm{mM})$ DMEM/F12 with $10 \mathrm{nM}$ insulin for $6 \mathrm{~h}$. Control cells were incubated in this medium for an additional $24 \mathrm{~h}$. After $6 \mathrm{~h}, 1 \mu \mathrm{M}$ insulin (In) plus $1 \mu \mathrm{M}$ rosiglitazone (Rosi) were added to some cells and incubation was continued for $24 \mathrm{~h}$. Also at $6 \mathrm{~h}$, the MAPK inhibitor, PD 98059 at $25 \mu \mathrm{M}$ (PD) or the PI3K inhibitor, LY 294002 at $10 \mu \mathrm{M}$ (LY) were added along with In + Rosi; incubation was continued for $24 \mathrm{~h}$. Total RNA was extracted for detecting AdipoR1, AdipoR2, and $\beta$ actin gene expression by Northern analysis. The results are the means of four independent experiments using cells isolated from four different pigs and the average of the $24 \mathrm{~h}$ control medium data was set to 100 with other data expressed as relative abundance compared to the control value. Each bar represents the mean \pm S.E.M. and mRNA values were normalized to $\beta$-actin. Data were analyzed by ANOVA; means for AdipoR2 without a common letter differ significantly, $P \leq 0.05$.

integrity of RNA was determined by examination of the $18 \mathrm{~S}$ and 28S ribosomal RNA bands after electrophoresis. The RNA was quantified by spectrophotometry at $260 \mathrm{~nm}$ and stored at $-70^{\circ} \mathrm{C}$. Total RNA $(10 \mu \mathrm{g}$ of each sample) was electrophoresed and transferred to nylon membranes for Northern analysis following the procedure described by Liu et al. [23]. The porcine adiponectin, AdipoR1, AdipoR2, and $\beta$-actin probe sequences were previously described $([16,18]$, Table 1$)$. Probes were labeled with $\mathrm{P}^{32} \mathrm{dC}$ by PCR amplification. Hybridization blotting images were quantified using a Typhon 9200 phosphorimage scanner and ImageQuant TL v2005 software (GE). The densitometric value for an individual transcript in a sample lane was normalized to the densitometric value for the $\beta$-actin mRNA in the same lane. 

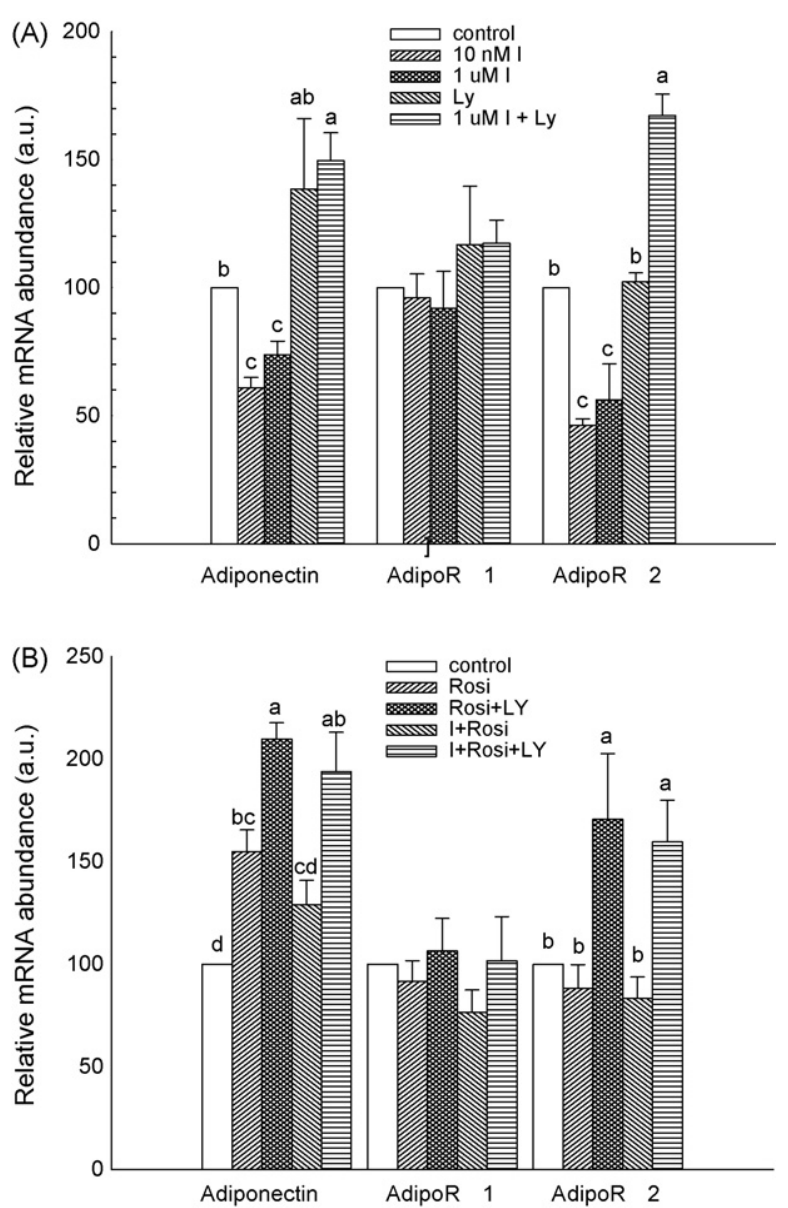

Fig. 5. Insulin inhibits and rosiglitazone increases expression of AdipoR2 through the PI3K pathway. Porcine S/V cells were differentiated for 9 days and then differentiated adipocytes were cultured in low glucose $(7.78 \mathrm{mM}) \mathrm{DMEM} / \mathrm{F} 12$ without $10 \mathrm{nM}$ insulin for $6 \mathrm{~h}$, then $10 \mathrm{nM}$ insulin(10 nM In), $1 \mu \mathrm{M}$ insulin(In), $1 \mu \mathrm{M}$ rosiglitazone (Rosi), or $10 \mu \mathrm{M}$ LY 294002 (LY), or combinations were added to separate plates for $24 \mathrm{~h}$. Total RNA was extracted for detecting adiponectin, AdipoR1, AdipoR2, and $\beta$-actin gene expression by Northern analysis. The results are the means of four independent experiments using cells isolated from four different pigs. The average of the $24 \mathrm{~h}$ control medium data for each gene was set to 100 with other data for that gene expressed as relative abundance to the control value. Each bar represents the mean \pm S.E.M. and mRNA values were normalized to $\beta$-actin. Data were analyzed by ANOVA; means for a given gene without a common letter differ significantly, $P \leq 0.05$, from the control value for that gene.

\subsection{Statistical analysis}

Data were presented as mean \pm S.E.M. After verification of the homogeneity of variances, data were analyzed by ANOVA to determine the significance of major treatment effects. For the first experiment, the effect of days of differentiation was determined. For the second experiment, the effects of insulin, rosiglitazone, and their interactions were determined. For the third experiment, the effects of insulin signaling pathway blockers were determined. Duncan's new multiple-range test was used to evaluate differences among means (SAS Inst., Inc., Cary, NC) for all experiments. A significant difference was indicated at $P \leq 0.05$. It should be noted that our results represent data obtained in vitro from 3 or 4 replicates, each using cells isolated from a different pig. Extrapolation to the pig in vivo and to all breeds of pigs must be tentative.

\section{Results}

\subsection{Expression of adiponectin and AdipoR genes during porcine adipocyte differentiation}

Expression of both adiponectin and AdipoR2 increased during adipocyte differentiation, whereas the expression of AdipoR1 increased during the initial 3 days with no further increase during the later stages of differentiation (Fig. 2). The data suggest that either AdipoR2 is more sensitive than AdipoR1 to the hormones present in the adipocyte cell culture medium or that the AdipoR 2 is a more important receptor mediating adiponectin function in the differentiated porcine adipocyte.

\subsection{Effects of insulin and rosiglitazone on expression of adiponectin and AdipoRs}

Treatment with a high concentration of insulin $(1 \mu \mathrm{M})$ for 2-24 $\mathrm{h}$ did not change the expression of adiponectin or the AdipoRs (Fig. 3). Because in all treatments, there was $10 \mathrm{nM}$ of insulin in the pre-incubation medium, we cannot exclude the possibility that this $10 \mathrm{nM}$ insulin was great enough to suppress the expression of adiponectin and AdipoR genes so that the treatment with $1 \mu \mathrm{M}$ insulin had no additional effect. The PPAR $\gamma$ agonist, rosiglitazone alone did not increase the expression of adiponectin or the AdipoRs (Fig. 3). However, the combination of a high-insulin concentration $(1 \mu \mathrm{M})$ plus rosiglitazone $(1 \mu \mathrm{M})$ increased expression of adiponectin and AdipoR2 in porcine adipocytes.

In order to clarify the relationship between insulin and the PPAR $\gamma$ agonist in regulating the expression of AdipoRs, we used insulin signaling pathway inhibitors to block phosphatidylinositol 3-kinase (PI3K) or mitogen-activated protein kinase (MAPK). Expression of AdipoR2, but not AdipoR1 mRNA was increased in the presence of $1 \mu \mathrm{M}$ insulin $+1 \mu \mathrm{M}$ rosiglitazone (Fig. 4), confirming data in Fig. 3, panels A and C. Addition of the MAPK inhibitor, PD 98059 had no effect on expression of AdipoR1 or AdipR2 mRNA. However, 
Table 1

List of the Northern analysis probes

\begin{tabular}{|c|c|c|c|}
\hline Genes $^{\mathrm{a}}$ & Primers $^{b}$ & Source of primers & Size (bp) \\
\hline Adiponectin & S 5'-GCTCAGGATGCTGTTGTTGG-3' & Pig & 768 \\
\hline (AY589691) & A 5'-TGGTGGAGGCTCTGAGTTGG-3' & & \\
\hline AdipoR1 & S 5'-AGGTACCAGCCAGATGTCTT-3' & Human & 1220 \\
\hline (AY578142) & А 5'-СТСТTCСТСТCACTTCAGCA-3' & & \\
\hline AdipoR2 & S 5'-AAAGGCTTGGGTATCCCATG-3' & Human & 1391 \\
\hline (AY606803) & A $5^{\prime}$-CTCCTCTGGTACTGGCATCA-3' & & \\
\hline$\beta$-Actin & S 5'-GTGGGCCGCTCTAGGCACCA-3' & Mouse & 245 \\
\hline (AF054837) & A 5'-CGGTTGGCCTTAGGGTTCAGGGGGG-3' & & \\
\hline
\end{tabular}

a GenBank accession number is indicated parenthetically.

b $\mathrm{S}$ : sense; A: antisense.

the AdipoR2 mRNA was increased when the PI3K signal pathway was inhibited by addition of LY 294002, suggesting that insulin may decrease the expression of AdipoR2 through the PI3K pathway.

In order to exclude the possibility that $10 \mathrm{nM}$ insulin (used in most experiments to maintain cell viability) suppressed adiponectin or AdipoRs gene expression, we designed another experiment to clarify the interaction of insulin and a PPAR $\gamma$ agonist on adiponectin and AdipoRs gene expression. After treating with insulin-free medium for $6 \mathrm{~h}$, addition of $10 \mathrm{nM}$ insulin reduced both adiponectin and AdipoR2 mRNAs (Fig. 5A), indicating a minute amount of insulin suppresses the expression of adiponectin and AdipoR2 genes. Addition of the PPAR $\gamma$ agonist, rosiglitazone for $24 \mathrm{~h}$ to differentiated adipocytes previously cultured in medium without insulin for $6 \mathrm{~h}$ significantly increased adiponectin mRNA expression, but not AdipoR2 mRNA (Fig. 5B). The PI3K inhibitor, LY 294002, promoted the expression of both adiponectin and AdipoR2 mRNAs (Fig. 5), even in the presence of insulin (Fig. 5A) and insulin + rosiglitazone (Fig. 5B). Hence, these findings suggest that insulin suppresses the expression of adiponectin and AdipoR2 mRNAs through the PI3K pathway. The exact mechanism for the increased mRNA expression in the presence of the PI3K inhibitor is yet to be determined.

\section{Discussion}

Adiponectin is an adipocyte-derived hormone that can improve insulin sensitivity by regulating glucose utilization and fatty acid metabolism. Overexpression of adiponectin not only promotes adipogenesis by prolonging and enhancing the key adipogenic transcription factors, i.e., PPAR $\gamma$, CCAAT/enhancer-binding protein $\alpha$, and adipocyte determination and differentiation factor 1/sterol-regulatory element-binding protein 1c, but also stimulates glucose uptake by increasing glucose transporter 4 gene expression [24]. Adiponectin increases
PPAR $\gamma 2$ expression in porcine adipocytes, suggesting that adiponectin enhances or maintains porcine adipocyte morphology through the regulation of PPAR $\gamma$ and other adiponectin target genes [25]. The expression of both AdipoR1 and AdipoR2 genes was downregulated in adipocytes overexpressing adiponectin [24] and adiponectin downregulates its own production and the expression of its AdipoR2 receptor in transgenic mice [26]. These results suggest that adiponectin may act in an autocrine or paracrine fashion to regulate the function of its receptors in adipose tissue. The receptor downregulation may decrease the adiponectin responses to slacken the adipogenic progression; however, receptor down-regulation may only occur when adiponectin concentration reaches extreme levels, as in the overexpressing cells and mice.

In 3T3-L1 adipocytes cultured with DMEM $+10 \%$ FBS, rosiglitazone does not affect the expression of adiponectin, even though there is a PPAR-response element (PPRE) in the adiponectin promoter region [27]. Rosiglitazone does increase plasma adiponectin concentration in humans and mice in vivo [27,28]. The authors suggest that an adequate insulin concentration may be necessary to observe the rosiglitazone-stimulated increase in the expression of the adiponectin gene [27]. With porcine adipocytes, we observed no effect of insulin or rosiglitazone, but the combination of the two increased expression of adiponectin and AdipoR2 mRNAs. Similarly, AdipoR2, but not AdipoR1 mRNA, was increased by rosiglitazone treatment in mouse primary adipocytes, and HepG2 hepatocytes cultured with FBS [13,20]. Combined, these observations suggest that rosiglitazone may activate the expression of adiponectin through the insulin signaling pathway. In contrast, Tsuchida et al. [29] recently demonstrated that insulin suppressed the expression of AdipoRs via the PI3K/Foxo1-dependent pathway in rodent hepatocytes and myocytes. Although treatment with a high concentration of insulin $(1 \mu \mathrm{M})$ alone did not down-regulate the expression of AdipoR2 
mRNA in porcine adipocytes, the expression of AdipoR2 mRNA was increased when the PI3K pathway was inhibited by addition of LY 294002. These data suggest that insulin at least partially suppressed the expression of AdipoR2 via the PI3K pathway. A direct insulin-induced inhibition of AMPK activity through the PI3K/Akt pathway in the heart [30], provides a potential mechanism by which the expression of AdipoRs are inhibited by insulin in adipocytes.

In pigs, the normal concentration of insulin is maintained at $106 \pm 12.5 \mathrm{pM}$ and increased to $850 \pm 137.5 \mathrm{pM} 30 \mathrm{~min}$ post-prandially [31]. Porcine adipocytes respond poorly to insulin in vitro and require $100 \mathrm{nM}$ insulin for optimal adipogenesis or differentiation in vitro [32,33]. At 1 or even $10 \mu \mathrm{M}$ insulin differentiation is slightly, but not significantly reduced [33]. We used $1 \mu \mathrm{M}$ insulin plus a PPAR $\gamma$ ligand (not used by [33]) in our differentiation medium to achieve a very high degree of differentiation, i.e., more than $90 \%$ of the cells contained oil red O-stained material. Optimal stimulation of lipogenesis requires from approximately $10 \mathrm{nM}$ to $1 \mu \mathrm{M}$ insulin $[32,34]$. The highinsulin concentration $(1 \mu \mathrm{M})$, used in our experiments, is required to demonstrate modulation of the expression of the adiponectin gene in 3T3-L1 cells [19] and is similar to the conditions in type 2 diabetes or other hyperinsulinemia-induced metabolism syndromes. In mammals, insulin concentration changes during feeding/fasting do not affect the abundance of adiponectin [16,35]. Whether insulin physiologically regulates the expression of adiponectin and its receptors awaits further investigation.

Regulation of adiponectin function may have therapeutic potential for treating type 2 diabetes mellitus and obesity. Over-expression of adiponectin in mice improves insulin resistance [36], whereas adiponectindeficient mice are mildly insulin resistant [6,7]. Mice lacking adiponectin show decreased hepatic insulin sensitivity [37]. In addition, mutation in the adiponectin and AdipoR genes and obesity appear to be hypoadiponectinemic and associated with type 2 diabetes [38].

It should be noted that in the presence of $10 \mathrm{nM}$ insulin, rosiglitazone had no effect on the expression of AdipoR2. This result confirmed data from our experiment (Fig. 4) and was similar to that reported in differentiated human myotubes [39,40], indicating that the PPAR $\gamma$ agonist may improve insulin sensitivity by increasing the serum adiponectin level with no effect on its receptors. Recent research indicates that administration of a thiazolidinedione to human type 2 diabetes mellitus patients to improve insulin sensitiv- ity and increase adiponectin levels does not affect the expression of AdipoR1 and AdipoR2 in muscle and adipose tissue [41]. Although rosiglitazone may require the presence of insulin to increase the expression of adiponectin and AdipoR 2 genes in porcine adipocytes, the effect of rosiglitazone may be to reverse the inhibitory effect of insulin.

In conclusion, the expression of the adiponectin and AdipoR2 mRNAs is more strongly inhibited by insulin and stimulated by the PPAR $\gamma$ agonist, rosiglitazone than the AdipoR1 mRNA in porcine adipocytes. This is the first study to report that the insulin effect on inhibiting the expression of porcine AdipoR2 was mediated through the PI3K pathway as indicated by reversal of the effect in the presence of the PI3K inhibitor, LY 294002. Therefore, understanding the interaction between insulin, PPAR $\gamma$ and expression of adiponectin and its receptors will provide mechanisms that may lead to control of adipose fat deposition and to the treatment of type 2 diabetes.

\section{Acknowledgements}

This work was funded by National Science Council in Taiwan. We thank W.M. Cheng for his technical support.

\section{References}

[1] Scherer PE, Williams S, Fogliano M, Baldini G, Lodish HF. A novel serum protein similar to $\mathrm{C} 1 \mathrm{q}$, produced exclusively in adipocytes. J Biol Chem 1995;270:26746-9.

[2] Hu E, Liang P, Spiegelman BM. AdipoQ is a novel adipose-specific gene dysregulated in obesity. J Biol Chem 1996;271:10697-703.

[3] Maeda K, Okubo K, Shimomura I, Funahashi T, Matsuzawa Y, Matsubara K. cDNA cloning and expression of a novel adipose specific collagen-like factor, apM1 (AdiPose Most abundant gene transcript 1). Biochem Biophys Res Commun 1996;221:286-9.

[4] Kadowaki T, Yamauchi T. Adiponectin and adiponectin receptors. Endocr Rev 2005;26:439-51.

[5] Fruebis J, Tsao TS, Javorschi S, Ebbets-Reed D, Erickson MR, Yen FT, et al. Proteolytic cleavage product of $30-\mathrm{kDa}$ adipocyte complement-related protein increases fatty acid oxidation in muscle and causes weight loss in mice. Proc Natl Acad Sci USA 2001;98:2005-10.

[6] Kubota N, Terauchi Y, Yamauchi T, Kubota T, Moroi M, Matsui $\mathrm{J}$, et al. Disruption of adiponectin causes insulin resistance and neointimal formation. J Biol Chem 2002;277:25863-6.

[7] Maeda N, Shimomura I, Kishida K, Nishizawa H, Matsuda M, Nagaretani H, et al. Diet-induced insulin resistance in mice lacking adiponectin/ACRP30. Nat Med 2002;8:731-7.

[8] Yamauchi T, Kamon J, Waki H, Terauchi Y, Kubota N, Hara $\mathrm{K}$, et al. The fat-derived hormone adiponectin reverses insulin resistance associated with both lipoatrophy and obesity. Nat Med 2001;7:941-6. 
[9] Spranger J, Kroke A, Mohlig M, Bergmann MM, Ristow M, Boeing $\mathrm{H}$, et al. Adiponectin and protection against type 2 diabetes mellitus. Lancet 2003;361:226-8.

[10] Maeda N, Takahashi M, Funahashi T, Kihara S, Nishizawa H, Kishida K, et al. PPARgamma ligands increase expression and plasma concentrations of adiponectin, an adipose-derived protein. Diabetes 2001;50:2094-9.

[11] Yu JG, Javorschi S, Hevener AL, Kruszynska YT, Norman RA, Sinha M, et al. The effect of thiazolidinediones on plasma adiponectin levels in normal, obese, and type 2 diabetic subjects. Diabetes 2002;51:2968-74.

[12] Chinetti G, Zawadski C, Fruchart JC, Staels B. Expression of adiponectin receptors in human macrophages and regulation by agonists of the nuclear receptors PPARalpha, PPARgamma, and LXR. Biochem Biophys Res Commun 2004;314:151-8.

[13] Tsuchida A, Yamauchi T, Takekawa S, Hada Y, Ito Y, Maki $\mathrm{T}$, et al. Peroxisome proliferator-activated receptor (PPAR)alpha activation increases adiponectin receptors and reduces obesityrelated inflammation in adipose tissue: comparison of activation of PPARalpha, PPARgamma, and their combination. Diabetes 2005;54:3358-70.

[14] Seo JB, Moon HM, Noh MJ, Lee YS, Jeong HW, Yoo EJ, et al. Adipocyte determination- and differentiation-dependent factor $1 /$ sterol regulatory element-binding protein $1 \mathrm{c}$ regulates mouse adiponectin expression. J Biol Chem 2004;279:22108-17.

[15] Yamauchi T, Kamon J, Ito Y, Tsuchida A, Yokomizo T, Kita S, et al. Cloning of adiponectin receptors that mediate antidiabetic metabolic effects. Nature 2003;423:762-9.

[16] Ding ST, Liu BH, Ko YH. Cloning and expression of porcine adiponectin and adiponectin receptor 1 and 2 genes in pigs. $\mathrm{J}$ Anim Sci 2004;82:3162-74.

[17] Suryawan A, Hu CY. Effect of serum on differentiation of porcine adipose stromal-vascular cells in primary culture. Comp Biochem Physiol Comp Physiol 1993;105:485-92.

[18] Liu BH, Kuo CF, Wang YC, Ding ST. Effect of docosahexaenoic acid and arachidonic acid on the expression of adipocyte determination and differentiation-dependent factor 1 in differentiating porcine adipocytes. J Anim Sci 2005;83:1516-25.

[19] Fasshauer M, Klein J, Neumann S, Eszlinger M, Paschke R. Hormonal regulation of adiponectin gene expression in 3T3L1 adipocytes. Biochem Biophys Res Commun 2002;290: 1084-9.

[20] Sun X, Han R, Wang Z, Chen Y. Regulation of adiponectin receptors in hepatocytes by the peroxisome proliferatoractivated receptor-gamma agonist rosiglitazone. Diabetologia 2006;49:1303-10.

[21] Pereira RI, Draznin B. Inhibition of the phosphatidylinositol 3'kinase signaling pathway leads to decreased insulin-stimulated adiponectin secretion from 3T3-L1 adipocytes. Metab Clin Exp 2005;54:1636-43.

[22] Chomczynski P, Sacchi N. Single-step method of RNA isolation by acid guanidinium thiocyanate-phenol-chloroform extraction. Anal Biochem 1987;162:156-9.

[23] Liu BH, Wang YC, Cheng WM, Shen TF, Ding ST. The effects of docosahexaenoic acid oil and soybean oil on the expression of lipid metabolism related mRNA in pigs. Asian Austral J Anim Sci 2005; 18:1451-6.

[24] Fu Y, Luo N, Klein RL, Garvey WT. Adiponectin promotes adipocyte differentiation, insulin sensitivity, and lipid accumulation. J Lipid Res 2005;46:1369-79.

[25] Ajuwon KM, Spurlock ME. Adiponectin inhibits LPS-induced NF-kappaB activation and IL-6 production and increases
PPARgamma2 expression in adipocytes. Am J Physiol Regul Integr Comp Physiol 2005;288:R1220-5.

[26] Bauche IB, Ait El Mkadem S, Rezsohazy R, Funahashi T, Maeda N, Miranda LM, et al. Adiponectin downregulates its own production and the expression of its AdipoR2 receptor in transgenic mice. Biochem Biophys Res Commun 2006;345:141424.

[27] Combs TP, Wagner JA, Berger J, Doebber T, Wang WJ, Zhang BB, et al. Induction of adipocyte complement-related protein of $30 \mathrm{kDa}$ by PPARgamma agonists: a potential mechanism of insulin sensitization. Endocrinology 2002;143:9981007.

[28] Kralisch S, Klein J, Bluher M, Paschke R, Stumvoll M, Fasshauer M. Therapeutic perspectives of adipocytokines. Expert Opin Pharmacother 2005;6:863-72.

[29] Tsuchida A, Yamauchi T, Ito Y, Hada Y, Maki T, Takekawa $\mathrm{S}$, et al. Insulin/Foxo1 pathway regulates expression levels of adiponectin receptors and adiponectin sensitivity. J Biol Chem 2004;279:30817-22.

[30] Kovacic S, Soltys CL, Barr AJ, Shiojima I, Walsh K, Dyck JR. Akt activity negatively regulates phosphorylation of AMP-activated protein kinase in the heart. J Biol Chem 2003;278:39422-7.

[31] Rayner DV. The relationships between glucose absorption and insulin secretion and the migrating myoelectric complex in the pig. Exp Physiol 1991;76:67-76.

[32] Mersmann HJ. The effect of insulin on porcine adipose tissue lipogenesis. Comp Biochem Physiol 1989;94B:709-13.

[33] Suryawan A, Swanson LV, Hu CY. Insulin and hydrocortisone, but not triiodothyronine, are required for the differentiation of pig preadipocytes in primary culture. J Anim Sci 1997;75: 105-11.

[34] Mersmann HJ, Hu CY. Factors affecting measurements of glucose metabolism and lipolytic rates in porcine adipose tissue slices in vitro. J Anim Sci 1987;64:148-64.

[35] Merl V, Peters A, Oltmanns KM, Kern W, Born J, Fehm HL, et al. Serum adiponectin concentrations during a 72-hour fast in over- and normal-weight humans. Int J Obes 2005;29:9981001.

[36] Combs TP, Pajvani UB, Berg AH, Lin Y, Jelicks LA, Laplante $\mathrm{M}$, et al. A transgenic mouse with a deletion in the collagenous domain of adiponectin displays elevated circulating adiponectin and improved insulin sensitivity. Endocrinology 2004;145:367-83.

[37] Nawrocki AR, Rajala MW, Tomas E, Pajvani UB, Saha AK, Trumbauer ME, et al. Mice lacking adiponectin show decreased hepatic insulin sensitivity and reduced responsiveness to peroxisome proliferator-activated receptor gamma agonists. J Biol Chem 2006;281:2654-60.

[38] Kadowaki T, Yamauchi T, Kubota N, Hara K, Ueki K, Tobe $\mathrm{K}$. Adiponectin and adiponectin receptors in insulin resistance, diabetes, and the metabolic syndrome. J Clin Invest 2006;116:1784-92.

[39] Kaltenbach S, Staiger H, Weisser M, Haas C, Stumvoll M, Machicao $\mathrm{F}$, et al. Adiponectin receptor gene expression in human skeletal muscle cells is not regulated by fibrates and thiazolidinediones. Int J Obes (Lond) 2005;29:760-5.

[40] Li W, Tonelli J, Kishore P, Owen R, Goodman E, Scherer PE, et al. Insulin-sensitizing effects of thiazolidinediones are not linked to adiponectin receptor expression in human fat or muscle. Am J Physiol Endocrinol Metab 2007;292:E1301-7.

[41] Saltiel AR, Kahn CR. Insulin signalling and the regulation of glucose and lipid metabolism. Nature 2001;414:799-806. 